\title{
TOWARDS CREATION OF UNIFIED REGULATION ON SURROGACY IN EUROPE: RECENT TRENDS AND FUTURE PERSPECTIVES
}

DOI: 10.36740/WLek202012227

\author{
Roman A. Maydanyk, Kateryna V. Moskalenko \\ LAW SCHOOL OF TARAS SCHEVCHENKO NATIONAL UNIVERSITY OF KYIV, KYIV, UKRAINE
}

\begin{abstract}
The aim of this paper is to study the existing international legal framework, regulating international surrogacy agreements and to analyse the possibility of adoption of respective unified European legal instrument.

Materials and methods: The article is based on international legal acts, jurisprudence of the European Court of Human Rights, reports and scientific articles. The research is grounded on dialectical, formal logical methods, methods of synthesis and analysis, comparative legal method and the method of modelling.

Conclusions: The authors came to conclusion about the necessity of introducing of unified legal instrument dealing with international surrogacy cases. The article illustrates that the work towards harmonization of surrogacy in Europe started at the beginning of $21^{\text {st }}$ century and the experts group of the Hague Conference on Private International Law is currently working on drafting a respective protocol. The authors provide a list of questions that were not noticed by the mentioned experts but should be included in the protocol.
\end{abstract}

KEY WORDS: international surrogacy, harmonization of surrogacy regulation, European Court of Human Rights, Hague Conference on Private International Law, best interests of the child

Wiad Lek. 2020;73(12 p. II):2865-2870

\section{INTRODUCTION}

Surrogacy, as defined by the Oxford dictionary, is the practice of giving birth to a baby for another person or couple, usually because they are unable to have babies themselves [1]. Legal doctrine defines between traditional and gestational surrogacy, where in traditional surrogacy the surrogate mother is also the biological mother of a child she carries, while in gestational surrogacy the surrogate mother does not have any genetic link with the future baby. Normally, traditional surrogacy is strictly prohibited by the national legislators and if they choose to allow surrogacy - only gestational type is allowed.

Surrogacy can be further divided into commercial and altruistic. In accordance with commercial surrogacy model, the surrogate mother receives remuneration for carrying and giving birth to the baby. Altruistic surrogacy envisages that the surrogate mother does not receive any remuneration, however some jurisdictions allow the intending parents to compensate her expenses. The countries in Europe, that allow surrogacy, tend to opt for altruistic surrogacy.

There is no consensus in Europe on how to regulate surrogacy. A broad study shows that the approach of the national legislators in Europe may fall within following four categories:

- no regulation for surrogacy is provided, however in practice surrogacy contracts are signed and enforced (e.g., Belgium);

- surrogacy is not allowed, however the discussions on allowing it in the future are held (e.g., Spain);
- surrogacy is allowed, and the legislator provides for the regulation on surrogacy (e.g., Ukraine, Russia, Greece); - surrogacy is strictly forbidden by the law (e.g., Germany, France) [2].

Global statistics show that a number of surrogacy cases, especially a number of concluded international surrogacy contracts was increasing each year until the beginning of 2020. Global COVID-19 pandemic has slowed down continuing growth of surrogacy due to travel restrictions and restriction for the foreigners to cross the borders of the countries, implemented by most of legislators in Europe. This tendency is believed to continue until the end of global pandemic and is supposed to end with the removal of travel restrictions. Before the coronavirus restrictions, surrogacy was recognized to be an emerging global market, estimated "to cross $\$ 27.5$ billion by 2025 " in accordance with the data of Global Market Insights [3].

Couples where one or both of partners were infertile were seeking a possibility to enter into surrogacy contract either in their jurisdiction or were opting for reproductive tourism. The reasons for such tourism may be different: trying to avoid legal restrictions for surrogacy provided by the national legislation of the intending parents (e.g., access to surrogacy only to heterosexual married couples, necessity of genetic link with a future baby of at least of one intending parents, impossibility to use ova or sperm donors, outlawing of surrogacy etc.) or trying to save finances (as in certain Eastern-European jurisdictions, like Ukraine or Russia the price for surrogacy may be much 
less than in the other European countries where surrogacy is allowed). In these cases, international surrogacy takes place, when the intending parents are the nationals of one (or two) country (ies), while the surrogacy itself is happening in another country, where, usually, surrogate mother resides. The risks that the stakeholders may face were broadly studied in the jurisprudence. For instance, R. Deonandan has defined the following legal risks:

- to the country of origin of the intended parents (when the country calls the tourists for liability for the acts that are legal in the country of destination but are illegal in the home country of the intended parents);

- to the destination country (if needs of emerging surrogacy industry will influence the laws of the destination country);

- to the surrogate mothers (doubts whether surrogate mothers are participating in surrogacy programs because of their low economic income or because they really decide so);

- to the clinics;

- to brokering parties;

- to the children born as a result of surrogacy [4].

As it was stated in the report, prepared by the Permanent Bureau of the Hague Conference of Private International Law, international surrogacy cases can result in the problems concerning "the establishment and / or recognition of the child's legal parentage and the legal consequences which flow from such a determination (e.g., the child's nationality, immigration status, who has parental responsibility for the child, who is under a duty to maintain the child, etc.)" [5].

Notwithstanding a significant number of risks and problems, arising out of international surrogacy, there is no unified international legal instrument dealing with these problems.

\section{THE AIM}

The aim of this paper is to study the existing international legal framework regulating international surrogacy agreements and to analyse the possibility of respective unified European legal instrument adoption.

\section{MATERIALS AND METHODS}

The article is based on international universal and regional European legal instruments, the jurisprudence of the European Court of Human Rights, reports of the European Parliament, International Commission of the Civil Status, Hague Conference on Private International Law and the UN Special Rapporteur on the sale and sexual exploitation of children, including child prostitution, child pornography and other child sexual abuse material and scientific articles. The research is grounded on dialectical, formal logical methods, methods of synthesis and analysis, comparative legal method and the method of modelling.

\section{REVIEW AND DISCUSSION}

As it was stated above, there is currently no unified legal instrument dealing specifically with the international surrogacy. Fragmentary regulation is provided by both universal and regional international instruments.

Among universal legal acts one may name Universal Declaration of Human Rights (1948) [6], Art. 15 of which lays down that "everyone has the right to a nationality. No one shall be arbitrarily deprived of his nationality nor denied the right to change his nationality". This article is supposed to provide a minimum standard for a child, born as a result of international surrogacy, however in practice this article does not help to combat the cases of stateless children, because it does not answer the question, which state should grant such nationality and what the relevant mechanism should be [7]. Pursuant to Parts 2,3 of Art. 24 of the International Covenant on Civil and Political Rights (1966) [8], "every child shall be registered immediately after birth and shall have a name. Every child has the right to acquire a nationality". As B. Ni Ghrainne and A. McMahon have observed, as in the case with the Universal Declaration of Human Rights, it is unclear, which state should grant a nationality to the child and upon which conditions. Moreover, it is stated in Point 8 of the General Comment 17 of the Human Rights Committee, that the States are not obliged to give their nationality to every child born in their territory [7]. However, the General Comment provides for requirement of the States to "adopt every appropriate measure, both internally and in cooperation with other States, to ensure that every child has a nationality when he is born" [9]. Drafting and adoption of Convention on International Surrogacy, containing the norms ensuring that the children are not stateless, can be an appropriate measure in the light of the mentioned General Comment. Principle 3 of the Universal Declaration of the Rights of the Child (1959) [10] stipulates that the child shall be entitled from his birth to a name and nationality. Under Principle 6 of the same Declaration, "the child, for the full and harmonious development of his personality, needs love and understanding. He shall, wherever possible, grow up in the care and under the responsibility of his parents, and, in any case, in an atmosphere of affection and of moral and material security; a child of tender years shall not, save in exceptional circumstances, be separated from his mother.... The mentioned principles of the Universal Declaration are declarative and do not identify the responsible states and the mechanism of ensuring that the child is provided with the nationality and is growing up in the care and under the responsibility of his parents. The Convention of the Rights of the Child (1989) [11] operates with the term "best interests of the child", which shall be a primary consideration in all actions concerning children, whether undertaken by public or private social welfare institutions, courts of law, administrative authorities, administrative authorities or legislative bodies (Art. 3). In our opinion, the concept of the best interests of the child should be a basis when drafting the Convention on International Surrogacy. The Convention of the Rights of the Child repeats a number of guarantees, provided by the mentioned international legal acts, such as: registration immediately after birth, having the right from birth to a name and the right to acquire a 
nationality (Art. 7) and ensuring "that a child shall not be separated from his or her parents against their will except when competent authorities subject to judicial review determine, in accordance with applicable law and procedures, that such separation is necessary for the best interests of the child (Art. 8). Optional Protocol to the Convention on the Rights of the Child on the sale of children, child prostitution and child pornography (2000) [12] lays down a holistic approach to the trafficking in children. In accordance with the Point a) of Art. 2, for the purposes of the present Protocol: a) sale of children means any act or transaction whereby a child is transferred by any person or group of persons to another for remuneration or any other consideration. While surrogacy is a form of assisted human reproduction, that allows infertile couples to exercise their reproductive right, and is not a sale of children, however in the circumstances when it is not properly regulated, in opinion of Ms. Maud de Boer-Buquicchio, Special Rapporteur on the sale and sexual exploitation of children, including child prostitution, child pornography and other child sexual abuse material, "surrogacy arrangements risk compromising the fundamental rights of the child to human dignity, the right to identify, including nationality, access to origins and the enjoyment of family life" [13].

There is a number of European regional legal instruments that also provide some rules, applicable in cross-national surrogacy. The Convention for the Protection of Human Rights and Fundamental Freedoms (1950) (hereinafter Convention) [14] protects the right to respect for private and family life (Art. 8), stipulating that "everyone has the right to respect for his private and family life, his home and his correspondence". Several cases involving international surrogacy was decided by the European Court of Human Rights (hereinafter - the ECHR), where the ECHR has interpreted Art. 8 of the Convention. For example, in the case of Menneson v. France (2014) [15] the ECHR has been guided by the best interests of the child and has decided that non-recognition of French authorities of the legal parent-child relationship between children born by a surrogate mother in the United States of America and the intended parents as violation of the children's right provided by Art. 8 of the Convention, despite the fact that surrogacy agreements in France contradict the public order and thus are null and void. One should notice that children were almost 14 years old when the decision of the ECHR became final. The ECHR came to the same conclusion in another well-known case - Labassee v. France (2014) [16]. It is interesting that the ECHR came with another conclusion in the case Paradiso and Campanelli v. Italy (2017) [17], where the Italian couple challenged the refusal of the authorized Italian authorities to recognise a parent-child relationship arisen as a result of surrogacy carried in Russia. In this case the child was not genetically related with the Italian spouses as a result of mistake (different gametes were used by the clinic) and the ECHR thus ruled that there was no family life between the child and the intended parents. As M. Ni, Shuilleabhain notes, in this case the ECHR "does not ascribe the same precedence to the "best interests" of the individual child. Instead, the interests of the affected child appear to rank in pari passu alongside the interests of the children more generally and the interest in curbing illegal conduct" [18]. As the ECHR decided in this case, "agreeing to let the child stay with the applicants, possibly with a view to becoming his adoptive parents, would have been tantamount to legalising the situation created by them in breach of important rules of Italian law". In 2019 the ECHR has issued the Advisory opinion concerning the recognition in domestic law of a legal parent-child relationship between a child born through a gestational surrogacy arrangement abroad and the intended mother, requested by the French Court of Cassation [19]. Being guided by the "best interests of the child", the ECHR has decided that despite the fact that surrogacy contradicts the public order under French law, there is a legal way to recognize a child-parent relationship with the intended mother that does not have genetic link with the child - adoption, that should be quick and effective. The Advisory opinion was used in the following cases, heard by the ECHR $-C$ and E v. France (2019) and D v. France (2020) [20]. It is also important to note that ECHR has supported a reproductive tourism in a number of its decisions - e.g., S.H.. and others v. Austria (2011) [21].

The Convention for the Protection of Human Rights and Dignity of the Human Being with regard to the Application of Biology and Medicine: Convention on Human Rights and Biomedicine (ETS No 164) (1997) [22] is another European instrument, providing a number of bioethical rules that can be of use in the international surrogacy cases - equitable access to health care (Art. 3), professional standards (Art. 4), requirements for informed consent (Art. 5), respect for private life in relation to information about his or her health (Art. 10), non-selection of child's sex except when serious hereditary sex-related disease is to be avoided etc.

The European Union has not adopted any harmonized rules on surrogacy. However, some applicable rules may be found in the Charter of Fundamental Rights of the European Union (2012) [23]. Under Part 3 of Art. 24 of the mentioned Charter, "every child shall have the right to maintain on a regular basis a personal relationship and direct contact with both his or her parents, unless that is contrary to his or her interests". Directive 2004/23/EC of the European Parliament and of the Council of 31 March 2004 on setting standards of quality and safety for the donation, procurement, testing, processing, preservation, storage and distribution of human tissues and cells [24] lays down the standards that can be used in cases where donor gametes are needed for surrogacy fulfilment in the EU.

There is no specialized legal instrument regulating surrogacy in Europe, which is of great concern of all the stakeholders involved and there's no surprise that several studies on harmonization of surrogacy in Europe have been carried up to date.

One of the first research towards surrogacy and maternal filiation was conducted in 2003 by the International Commission on Civil Status (ICCS), an international organization, aiming to facilitate collaboration between the states 
in the matters of civil status. The questions in the status of the maternal filiation were summarized in concept note "L'établissement de la filiation maternelle et les maternités de substitution dans les États de la CIEC". In 2014 another study was carried by the ICCS, dedicated to the surrogacy and child marital status [25].

"A comparative study on the regime of surrogacy in EU Member States" was issued by the European Parliament in 2013. The study considers different approaches EU can choose towards surrogacy regulation and studies, in particular, the possibility of framing surrogacy by either substantial harmonization, harmonization of conflict-oflaw rules or joining an international convention is studied. As a conclusion, the authors have noticed that it is necessary "to access the relationship between the EU, the Hague Conference on Private International Law and the ICCS in the field of surrogacy. Their work is progressing, and the EU should remain a key-actor in the negotiations and research" [26].

In 2010 a project on parentage and surrogacy was started by the Hague Conference on Private International Law. Following a profound research and studies, in March 2019 the experts' group decided to draft the convention "on the recognition of foreign judicial decisions on legal parentage", and "a separate protocol on the recognition of foreign judicial decisions on legal parentage rendered as a result of an international surrogacy arrangement (hereinafter - the Protocol)" [27]. Summing up the offers of the experts, the following views were expressed:

- a lot of experts offered that the Protocol should cover the legal parentage in the international surrogacy agreements only;

- the judgments concerning legal parentage of the child born by a surrogate should be delivered shortly after birth, possible criteria for the recognition of judgements on legal parentage were discussed;

- the possibility of certification to verify that surrogacy agreement was conducted in accordance with the Protocol was offered;

- the necessity to ensure free and informed consent of the surrogate;

- keeping the information on the child's origin to safeguard the right of the child to information about its genetic origin;

- role of intermediaries in the international surrogacy cases;

- possible "minimum standards concerning the eligibility and suitability of the surrogate mother, and the eligibility and suitability of the intending parent" and other questions" [27].

The experts outlined that the convention and the Protocol will be drafted and presented in the final report, which is planned on March 2022. If this ambitious and important project is completed as planned, we will have the draft of the instrument, having the potential to eliminate the problems of the stateless children and minimizing other risks listed in this article. Some of the scholars are sceptical about the success of any new convention on surrogacy, because there is little probability that the countries where surrogacy is banned would sign it, moreover, negotiations on such instrument would take years [7].

The study of legal literature shows that the desirable contents of such convention is much wider than was offered by the Hague Conference on Private International Law. For example, R. Pol offered draft provision of the proposed international instrument, including, among others, necessity of establishing the "Competent Authority" at the federal level of every state, which will be communicating between the contracting parties' establishing the "Governing Committee", being in charge of applications of intending parents and interested surrogate mothers to enter into international surrogacy agreement; establishing the authority for resolution of disputes [28]. M. Flatscher-Thoni, C. Voithofer have proposed adoption of ART Convention, containing pre-treatment measures (ensuring providing the patients with the necessary information); treatment measures (minimal legal standards of the relevant contracts should be met), post-treatment measures (installing of an arbitrary board) [29].

There is no doubt that the project conducted by the Hague Conference on Private International Law has the biggest potential to succeed among all the recent endeavours, however in our opinion, the list of questions it regulates should be extended. For example, the final report, available on the website of the project, does not contain the information on the authority which will have discretion to control fulfilment of the Protocol and the authority, which will decide the disputes between the parties to international surrogacy.

\section{CONCLUSIONS}

Parties to an international surrogacy contract and a baby (babies) born after the contract is fulfilled are facing several risks, the most dangerous of which entails leaving the children stateless and resulting in the situations when the child-parent relations are not recognized by the country of the intended parents' origin. There is no unified legal approach to avoid and resolve such issues provided at the international or regional (European) level.

Existing international, European and European Unions' legal instruments regulate some separate issues of international surrogacy cases, which do not provide practical solutions to existing problems. The ECHR has developed a few cases, dealing with international surrogacy, supporting, for example, a reproductive tourism or advising on ways of recognition of child-parent relations in the surrogacy cases with the intended parent who is not the biological parent of the child, however these rules do not substitute the international binding legal instrument. Sometimes from the moment of child birth to the moment when the decision of the ECHR is issued more than 10 years can pass and there is a need of the instrument that can deal with such cases on a rapid way.

The necessity of introducing of unified legal instrument dealing with international surrogacy cases is discussed during almost last two decades and the Hague Conference on Private International Law is currently drafting such protocol, the 
work is expected to be finished by March 2022. However, some questions that should be regulated by the Protocol, in our opinion, were not included in the Report of the Expert group as of March 2019. It is believed that the protocol shall also provide for authority which will have discretion to control fulfilment of the Protocol and the authority, which will decide the disputes between the parties to international surrogacy.

\section{REFERENCES}

1. Surrogacy, a definition of the Oxford Learner's Dictionaries. Available from:https://www.oxfordlearnersdictionaries.com/definition/english/ surrogacy?q=surrogacy [reviewed 2020.08.18].

2. González N. I. Regulating surrogacy in Europe: Common problems, diverse national laws. European Journal of Women's Studies. 2019; 26(2): 1-12. doi: 10.1177/1350506819835242.

3. Surrogacy Market revenue to cross $\$ 27.5$ billion by 2025 : Global Market Insights, Inc. Available from: https://www.globenewswire. com/news-release/2019/12/16/1960684/0/en/Surrogacy-Marketrevenue-to-cross-27-5-billion-by-2025-Global-Market-Insights-Inc. html [reviewed 2020.08.18].

4. Deonandan R. Trends in reproductive tourism and international surrogacy: ethical considerations and challenges for policy. Risk Management and Healthcare Police. 2015; 8: 111 - 119. doi: 10.2147/RMHP.S63862

5. Private international law issues surrounding the status of children, including issues arising from international surrogacy arrangements No. 11, March 2011. Available from: https://assets.hcch.net/ docs/f5991e3e-0f8b-430c-b030-ca93c8ef1c0a.pdf [reviewed 2020.08.20].

6. Universal Declaration of Human Rights dated December 10, 1948. Available from: https://www.ohchr.org/EN/UDHR/Documents/ UDHR_Translations/eng.pdf. [reviewed 2020.08.18].

7. Ni Ghrainne B., McMahon A. A Public International Law approach to safeguard nationality for surrogate-born children. Legal studies. 2017; 37 (2): 324 - 342. doi: 10.1111/lest.12146.

8. International Covenant on Civil and Political Rights dated December 16, 1966. Available from: http://www.un.org.ua/images/International_ Covenant_on_Civil_and_Political_Rights_CCPR_eng1.pdf[reviewed 2020.08.20].

9. CCPR General Comment No. 17: Article 24 (Rights of the child) dated April 7,1989. Available from: https://www.refworld.org/docid/45139b464. html [reviewed 2020.08.18].

10. Declaration of the Rights of the Child dated November 20, 1959. Available from: http://hrlibrary.umn.edu/instree/k1drc.htm [reviewed 2020.08.21].

11. Convention on the Rights of the Child dated November 20, 1989. Available from: https://www.ohchr.org/en/professionalinterest/pages/ crc.aspx [reviewed 2020.08.18].

12. Optional Protocol to the Convention on the Rights of the Child on the sale of children, child prostitution and child pornography dated May 25, 2000. Available from: https://www.ohchr.org/en/professionalinterest/ pages/opsccrc.aspx [reviewed 2020.08.21].

13. Statement by Ms. Maud De Boer-Buquicchio Special rapporteur on the sale and sexual exploitation of children, including child prostitution, child pornography and other child sexual abuse material at the 74th session of the General Assembly dated October 8, 2019. Available from: http://statements.unmeetings.org/media2/21998019/sr-on-saleand-sexual-exploitation-of-children-ga74-statement.pdf [reviewed 2020.08.30].
14. European Convention on Human Rights dated November 4, 1950. Available from:https://www.echr.coe.int/documents/convention_eng. pdf [reviewed 2020.08.18].

15. Case of Mennesson v. France (application No, 65192/11) Judgment of June 26, 2014. Available from: https://hudoc.echr.coe.int/ fre\#\%7B\%22itemid\%22:\%5B\%22001-145389\%22\%5D\%7D [reviewed 2020.08.18].

16. Case of Labassee v. France (application No, 65941/11) Judgment of June 26, 2014. Available from: https://hudoc.echr.coe.int/ eng\#\{ "itemid":["001-145180"]\} [reviewed 2020.08.18].

17. Case of Paradiso and Campanelli v. Italy (Application No. 25358/12) Judgment of January 24, 2017. Available from: https://hudoc.echr. coe.int/eng\#\%7B\%22fulltext\%22:\%5B\%22paradiso $\% 22 \% 5 \mathrm{D}, \% 22 \mathrm{~d}$ ocumentcollectionid2\%22:\%5B\%22GRANDCHAMBER\%22,\%22CHA MBER\%22\%5D,\%22itemid\%22:\%5B\%22001-170359\%22\%5D\%7D [reviewed 2020.08.30].

18. Ni Shuilleabhain M. Surrogacy, System Shopping and Article 8 of the European Convention on Human Rights. International Journal of Law, Policy and The Family. 2019;33: 104-122. Doi:0.1093/lawfam/eby021.

19. Advisory opinion concerning the recognition in domestic law of a legal parent-child relationship between a child born through a gestational surrogacy arrangement abroad and the intended mother, requested by the French Court of Cassation (Request no. P16-2018-001) dated April 10, 2019. Available from: https://hudoc. echr.coe.int/eng\#\%7B\%22itemid\%22:\%5B\%22003-63804648364383\%22\%5D\%7D [reviewed 2020.08.30].

20. Gestational surrogacy. Factsheet. Available from: https://www.echr. coe.int/Documents/FS_Surrogacy_eng.pdf [reviewed 2020.08.18].

21. Case of S.H. and others v. Austria (Application No. 57813/00) Judgment of April 1, 2010. Available from: https://hudoc.echr.coe. int/eng\#\%7B\%22itemid\%22:\%5B\%22001-98048\%22\%5D\%7D [reviewed 2020.08.30].

22. The Convention for the Protection of Human Rights and Dignity of the Human Being with regard to the Application of Biology and Medicine: Convention on Human Rights and Biomedicine (ETS No 164) (1997). Available from: https://rm.coe.int/168007ff98 [reviewed 2020.08.18].

23. Charter of Fundamental Rights of the European Union dated December 7, 2000. Available from: https://eur-lex.europa.eu/eli/treaty/ char_2012/0j [reviewed 2020.08.18].

24. Directive 2004/23/EC of the European Parliament and of the Council of 31 March 2004 on setting standards of quality and safety for the donation, procurement, testing, processing, preservation, storage and distribution of human tissues and cells. Available from: https:// eur-lex.europa.eu/legal-content/EN/TXT/?uri=celex\%3A32004L0023 [reviewed 2020.08.18].

25. Commission Internationale de l'État Civil (CIEC) par Jacques Massip, Frits Hondius, Chantal Nast et Frédérique Granet à jour au 1er janvier 2018. Available from: http://ciec1.org/SITECIEC/PAGE_Accueil/ hC8AADizuxxRbENWY1ZSU1VOCgA?WD_ACTION_=MENU\&ID=A22 [reviewed 2020.08.18].

26. A comparative study on the regime of surrogacy in EU Member States, 2013. Available from: https://www.europarl.europa.eu/RegData/ etudes/STUD/2013/474403/IPOL-JURI_ET(2013)474403_EN.pdf [reviewed 2020.08.18].

27. Report of the Experts' Group on the Parentage / Surrogacy Project (meeting from 290 ctober to 1 November 2019). Available from: https:// assets.hcch.net/docs/d435cffc-65ce-4047-b603-ff63ed20591c.pdf [reviewed 2020.08.18]. 
28. R. Pol. Proposing an International Instrument to address issues arising out of international surrogacy arrangements. Georgetown Journal of International Law. 2017; 48: 1309 - 1335. Available from: https://www. law.georgetown.edu/international-law-journal/wp-content/uploads/ sites/21/2018/05/48-4-Proposing-an-International-Instrument-toAddress-Issues-Arising-Out-of-International-Surrogacy-Arrangments. pdf [reviewed 2020.08.18].

29. M. Flatscher-Thoni, C. Voithofer. Should Reproductive Medicine Be Harmonized within Europe? European Journal of Health Law. 2015; 22. 61 - 74. doi: 10.U63//5718093-12341345.

\section{ORCID and contributionship:}

Roman A. Maydanyk: 0000-0003-1661-0535 A, D, E, F

Kateryna V. Moskalenko: 0000-0003-0152-9603 A, B, D, E

\section{Conflict of interests:}

The Authors declare no conflict of interests

\section{CORRESPONDING AUTHOR}

Kateryna V. Moskalenko

Law School of Taras Schevchenko

National University of Kyiv

Kyiv, Ukraine

tel: +380977175968

e-mail:kamoskalenko@gmail.com

Received: 26.08 .2020

Accepted: 30.11 .2020

A - Work concept and design, B - Data collection and analysis, C - Responsibility for statistical analysis, D-Writing the article, $\mathbf{E}$-Critical review, $\mathbf{F}$ - Final approval of the article 